\title{
Rats Offspring Exposed to Ipomoea Carnea and Handling during Gestation: Neurochemical Evaluation
}

\author{
Aline Schwarz ${ }^{1}$, Rosana Zoriki Hosomi ${ }^{2}$, Jorge Camilo Flório ${ }^{3}$, Maria Martha Bernardi ${ }^{3}$, \\ Silvana Lima Górniak ${ }^{3}$ and Helenice Souza Spinosa ${ }^{3}$ \\ ${ }^{I}$ Departamento de Análises Clínicas e Toxicológicas; Universidade Federal do Rio Grande do Norte; RN - Brasil. \\ ${ }^{2}$ Programa de Pós-Graduação em Ciências Biológicas; Instituto de Ciências Biológicas; Universidade de São \\ Paulo; São Paulo - SP - Brasil. ${ }^{3}$ Departamento de Patologia; Faculdade de Medicina Veterinária e Zootecnia; \\ Universidade de São Paulo; São Paulo - SP - Brasil
}

\begin{abstract}
The present study evaluated the central monoamine levels of male and female adult rat offspring exposed orally by gavage to 0.0, 0.7, 3.0 and $15.0 \mathrm{mg} / \mathrm{kg}$ I. carnea aqueous extract daily, from gestation day (GD) 5 to GD 21. Several alterations in the monoamine activity systems were observed. However, the major differences were noted between the $0.0 \mathrm{mg} / \mathrm{kg}$ and the no gavage control groups, showing that alterations showing that alterations were not due to the alterations to the aqueous extract. The control data showed that gavage and handling of dams were stressful enough to produce a significant decline in 3,4-dihydroxyphenylacetic acid (DOPAC) and an increase in vanilmandelic acid (VMA), indicating decreased dopamine (DA) and enhanced norepinephrine (NE) activity, respectively.
\end{abstract}

Key words: Ipomoea carnea; Neurotransmitter; Perinate; Rats; Stress

\section{INTRODUCTION}

During periods of drought, animals graze on $I$. carnea, a toxic tropical plant of the Convolvulaceae family (Tokarnia et al., 1960) which grows even in adverse climatic conditions (Keeler, 1988). After prolonged periods of $I$. carnea intake, animals exhibit a variety of clinical signs like depression, general weakness, loss of body weight, staggering gait, muscle tremors, ataxia, posterior paresis, and paralysis, followed by death if the ingestion is not interrupted (Idris et al., 1973; Damir et al., 1987; De Balogh et al., 1999). These toxic effects are attributed to the polyhydroxylated alkaloids swainsonine, calystegines $\quad \mathrm{B}_{1}, \quad \mathrm{~B}_{2}, \quad \mathrm{C}_{1} \quad$ and $2 \alpha-2 \beta$ - dihydroxynortropane detected in I. carnea (Asano et al., 2001), chemical toxins present mainly in the leaves of the plant.

Swainsonine is an indolizidine alkaloid and inhibits the action of the enzymes lysosomal $\alpha$ mannosidase and Golgi $\alpha$-mannosidase-II, resulting in lysosomal accumulation of incompletely processed oligosaccharides and alteration of the synthesis, processing and transport of glycoproteins (Stegelmeier et al., 1995). Calystegines are nortropanic alkaloids and inhibits the activity of glucosidases, galactosidases and xylosidases, lysosomal enzymes which act on oligosaccharide metabolism (Asano et al., 2000). The most characteristic lesion induced in animals grazing on I. carnea (De Balogh et al., 1999;

\footnotetext{
${ }^{*}$ Author for correspondence
} 
Schumaher-Henrique et al., 2003) is the presence of cytoplasmic vacuolization in nervous and peripheral cells as a consequence of the inhibition or absence of these enzymes (Stegelmeier et al., 1995).

It is well known that swainsonine and calystegines are weakly basic compounds. Perhaps these alkaloids can interact with barrier function and sites, thus being able to enter the brain and contact the fetus. Hydrophilic compounds can cross these barriers at high concentrations and accumulate in subcellular compartments with a low pH (Asano et al., 2000). Swainsonine may be actively accumulated in liver and kidney because of the extensive sugar activity present in these organs (Bowen et al., 1993). The same does not occur in the brain or placenta, which require high swainsonine doses to develop lesions (Stegelmeier et al., 1998). The concentrations of swainsonine in nervous system and placenta may be lower because the brain and placental barrier is relatively rich in lipids and swainsonine is less lipid soluble. In addition, cell damage is a consequence of both time of exposure to swainsonine and quantity of the compound. Thus, this damage is determined by the duration of exposure (Panter et al., 1999).

It has long been known that I. carnea intake for a prolonged period of time induces neurobehavioral effects in goats, cattle and sheep (Tokarnia et al., 1960). However, there are just a few reports about it effects on offspring if grazed by animals during the gestation period. Rats treated during gestation (DG 5 to DG 21) with the aqueous extract dose showed severe cytoplasmic vacuolation in liver, kidney, pancreas and thyroid tissues, and respective offspring, at adult age, showed no behavioral alterations (Schwarz et al., 2003).

The main objective of the present investigation was to study the possible toxic effects of I. carnea aqueous extract (AQE) on the central nervous system monoamine levels of the offspring exposed during the organogenesis and fetal developmental periods of gestation, complementing previous behavioral studies realized with these pups after exposition to the same extract, at the same doses and by the same manipulation method (Schwarz et al., 2003).

\section{MATERIAL AND METHODS}

\section{Plant}

I. carnea was planted in a $1,500 \mathrm{~m}^{2}$ field of the Centro de Pesquisa em Toxicologia Veterinária, Pirassununga, São Paulo state, Brazil. When the plants were mature, the leaves were taken (AprilJune, 2001) for extraction. Previous experiment studied chemical principles present in this plant (Schwarz et al., 2004).

\section{Preparation of the aqueous fraction extract (AQE)}

First the fresh leaves were triturated with ethyl alcohol $\left(97^{\circ} \mathrm{GL}\right)$ in a blender, macerated for $72 \mathrm{~h}$ in ethyl alcohol $\left(97^{\circ} \mathrm{GL}\right)$ and then filtered using a Büchner funnel. Next, the filtrate was evaporated under reduced pressure. The recovered ethyl alcohol was again returned to the leaf residue for a $24 \mathrm{~h}$ maceration period, followed by filtration and evaporation. This procedure was repeated two more times and the four products obtained were pooled, forming the final extract. The final extract was diluted in distilled water and filtered through filter paper. The filtered portion, ethanolic fraction, was treated with butanol and separated with a decantation funnel. This gave the aqueous extract (AQE), which was stored at $-20^{\circ} \mathrm{C}$.

\section{Animals}

Wistar rats from the Department of Pathology (Faculdade de Medicina Veterinária e Zootecnia, Universidade de São Paulo), weighing 180-200 g and aged approximately 90 days, were used. The animals were housed in polypropylene cages $(50 \mathrm{x}$ $40 \times 20 \mathrm{~cm}$ ) and were kept under controlled temperature $\left(22-24^{\circ} \mathrm{C}\right)$ on a $12: 12 \mathrm{~L} / \mathrm{D}$ light schedule (lights on at 6:00 a.m.), with free access to food and water. The animals used were maintained in accordance with The Guide for the Care and Use of Laboratory Animal, National Research Council, USA (1996).

\section{Procedures \\ Treatment}

Sexually naive female rats $(n=50)$ were mated with males previously tested as fertile (two females and one male per cage). Pregnancy was determined by the presence of spermatozoa in vaginal smears on the following morning, designated as gestation day 1 (GD1). Pregnant rats were removed and kept in separate cages. On GD5, the dams were divided into five groups 
$(\mathrm{n}=10)$. Four experimental groups were treated orally by gavage once a day from GD5 to GD 21 with $0.0,0.7,3.0$ or $15.0 \mathrm{mg} / \mathrm{kg}$ AQE. One no gavage control group were used (this group was employed to study the possible effects caused by the stress of the gavage procedure).

\section{Determination of monoamine levels}

All the pregnant rats were allowed to give birth and nurture their offspring normally. No crossfostering procedure was used. Parturition day was defined as PNO. On PN1, all the litters were examined externally and sexed. Litters were organized into groups of eight pups each, four males and four females, and the remaining pups were discarded. For the determination of monoamine levels 10 animals per group (5 males and 5 females) were employed. Only one animal (a male or a female) from each litter was used.

At PN120, male and female rats from control and experimental groups were decapitated. Brains were dissected on dry ice and prepared as described elsewhere (Felício et al., 1996). Briefly, the striatum (area related to motor function), cortex and hypothalamus (region relates to neuroendocrine function) were weighed and stored at $-80^{\circ} \mathrm{C}$ until neurochemical analysis are carried out. Following sample collections, perchloric acid was added to the tissues which were then homogenized by sonication for immediate determination of monoamine levels. Dopamine (DA) and its metabolites [3,4dihydroxyphenylacetic acid (DOPAC) and homovanillic acid (HVA)], serotonin (5HT) and its metabolite [5-hydroxyindolacetic acid (5HIAA)] and norepinephrine (NE) and its metabolites [3methoxy-4-hydroxyphenylglycol (MHPG) and vanilmandelic acid (VMA)] were measured by HPLC (Shimadzu, model 6A) using a C-1 column (Shimpak-ODS), an eletrochemical detector (Shimadzu, model 6A), a sample injector (15 and $20 \mu \mathrm{l}$ valve) and an integrator (Shimadzu, model 6A Chromatopac). Each sample was run for 18 min. The detection limit was $2 \mathrm{pg}$ for DA, DOPAC, NE, 5HT and 5HIAA, and $20 \mathrm{pg}$ for HVA.

\section{Statistical analysis}

Results are expressed as litter means \pm SEM as the maternal unit to avoid litter effects. Bartlett's test was used to determine data homogeneity. A twoway ANOVA were employed. The Tukey Kramer test was used as a post-hoc test when no interactions were observed between factors. In the case of a significant interaction, one-way ANOVA was applied. In all cases, results were considered significant for $p<.05$.

\section{RESULTS}

Neurotransmitter and metabolite levels were determined at 120 days of age. The data showed major differences in neurotransmitter levels and metabolite/neurotransmitter ratio between the 0 $\mathrm{mg} / \mathrm{kg}$ and the no gavage control groups. However, differences between the $0 \mathrm{mg} / \mathrm{kg}$ group and the experimental groups of male and female offspring were also observed. The neurotransmitter and metabolite statistical differences are presented in Table 1 (male data) and Table 2 (female data). The metabolite/neurotransmitter ratio data are shown in Fig. 1.

The two-way ANOVA revealed striatal DOPAC level alterations in factors treatment $[\mathrm{F}(4,1,43)=6.54, \quad \mathrm{p}<.001]$ and sex $[\mathrm{F}(4,1,43)=17.46, \quad \mathrm{p}<.001], \quad$ interaction: $\mathrm{F}(4,1,43)=2.61, \mathrm{p}<.05]$. The ordinary ANOVA employed showed decreased striatal DOPAC levels in male and female $0.0 \mathrm{mg} / \mathrm{kg}$ groups when compared to the no gavage control group and increased striatal DOPAC levels in both male $[F(4,20)=8.416, \quad \mathrm{p}<.001]$ and female $[F(4,20)=10.984, p<0.05] 0.7$ and $3.0 \mathrm{mg} / \mathrm{Kg}$ AQE groups. The two-way ANOVA revealed cortical and hypothalamic DA levels alterations in factors treatment and sex [cortical: treatment $\mathrm{F}(4,1,43)=3.77, \quad \mathrm{p}<.05, \quad$ sex $\quad \mathrm{F}(4,1,43)=60.10$, $\mathrm{p}<.001$; hypothalamical: treatment $\mathrm{F}(4,1,43)=6.14$, $\mathrm{p}<.001$, sex $\mathrm{F}(4,1,43)=57.94, \mathrm{p}<.001]$ with no interaction.

The Tukey Kramer test showed increased cortical DA levels in the male $0.0 \mathrm{mg} / \mathrm{kg}$ group when compared to the male no gavage control group and increased cortical, striatal and hypothalamic DOPAC levels on males when compared to females. Also, decreased cortical and hypothalamic DA levels in the $3.0 \mathrm{mg} / \mathrm{kg}$ male group, increased hypothalamic DA levels in the $15.0 \mathrm{mg} / \mathrm{kg}$ male group and decreased cortical DA levels in the 0.7 and $3.0 \mathrm{mg} / \mathrm{kg}$ female group. 
Table 1 - Effects of I. carnea AQE on central neurotransmitters (ng/g) of male adult rats exposed to different doses during gestation period (day 5 to 21 ).

\begin{tabular}{|c|c|c|c|c|c|c|}
\hline & \multirow[t]{2}{*}{ Region } & \multirow{2}{*}{$\begin{array}{c}\text { no gavage } \\
(\mathbf{n}=5)\end{array}$} & \multicolumn{4}{|c|}{ AQE (mg/kg) } \\
\hline & & & $0.0(n=5)$ & $0.7(n=5)$ & $3.0(n=5)$ & $15.0(n=5)$ \\
\hline \multirow[t]{3}{*}{ DOPAC } & Córtex & $28.3 \pm 7.4$ & $52.5 \pm 13.8$ & $40.9 \pm 5.0$ & $63.5 \pm 11.0$ & $55.4 \pm 16.6$ \\
\hline & Striatum & $2311.1 \pm 11.7$ & $1273.5 \pm 240.6^{\mathrm{a}^{* *}}$ & $2289.1 \pm 24.2^{\mathrm{b}^{* *}}$ & $2314.2 \pm 12.8^{\mathrm{b}^{* *}}$ & $1820.9 \pm 256.5$ \\
\hline & Hypothalamus & $101.3 \pm 9.5$ & $166.1 \pm 34.8$ & $193.4 \pm 19.3$ & $197.6 \pm 56.0$ & $170.3 \pm 45.7$ \\
\hline \multirow[t]{3}{*}{ DA } & Córtex & $38.3 \pm 3.9$ & $45.6 \pm 3.3^{\mathrm{a}^{*}}$ & $45.7 \pm 3.1$ & $38.5 \pm 5.4^{\mathrm{b}^{*}}$ & $45.2 \pm 6.5$ \\
\hline & Striatum & $8084.6 \pm 521.7$ & $7487.9 \pm 667.0$ & $7738.4 \pm 581.4$ & $6975.5 \pm 293.6$ & $8590.8 \pm 578.4$ \\
\hline & Hypothalamus & $227.6 \pm 6.1$ & $267.4 \pm 8.5$ & $229.5 \pm 15.8$ & $202.5 \pm 15.1^{\mathrm{b}^{*}}$ & $301.3 \pm 24.9^{\mathrm{b}^{*}}$ \\
\hline \multirow[t]{3}{*}{ VMA } & Cortex & $79.9 \pm 49.1$ & $58.6 \pm 17.5$ & $79.5 \pm 33.9$ & $108.9 \pm 67.1$ & $34.1 \pm 31.8$ \\
\hline & Striatum & $127.9 \pm 12.5$ & $437.9 \pm 86.1^{\mathrm{a}^{* * *}}$ & $146.6 \pm 32.8^{\mathrm{b}^{* *}}$ & $148.3 \pm 26.6^{\mathrm{b}^{* *}}$ & $399.6 \pm 85.7$ \\
\hline & Hypothalamus & $186.9 \pm 18.3$ & $119.1 \pm 14.1$ & $218.8 \pm 20.0$ & $212.2 \pm 70.5$ & $101.2 \pm 19.2$ \\
\hline \multirow[t]{3}{*}{$\mathrm{NE}$} & Cortex & $69.2 \pm 2.7$ & $72.2 \pm 6.7$ & $70.6 \pm 4.4$ & $89.7 \pm 8.6$ & $69.9 \pm 7.1$ \\
\hline & Striatum & $131.8 \pm 64.6$ & $247.2 \pm 38.6$ & $108.1 \pm 32.1$ & $87.0 \pm 17.8$ & $213.8 \pm 62.6$ \\
\hline & Hypothalamus & $242.7 \pm 19.5$ & $232.0 \pm 9.5$ & $241.3 \pm 13.7$ & $257.3 \pm 11.0$ & $266.4 \pm 17.8$ \\
\hline \multirow[t]{3}{*}{ 5HIIA } & Cortex & $197.9 \pm 12.1$ & $266.6 \pm 12.1$ & $282.5 \pm 21.2$ & $356.1 \pm 39.6^{\mathrm{b} * *}$ & $277.8 \pm 49.4$ \\
\hline & Striatum & $406.2 \pm 34.7$ & $489.8 \pm 20.8$ & $438.2 \pm 22.2$ & $582.0 \pm 79.9$ & $451.0 \pm 46.7$ \\
\hline & Hypothalamus & $395.2 \pm 28.1$ & $549.0 \pm 27.9^{\mathrm{a}^{*}}$ & $541.1 \pm 24.9$ & $431.3 \pm 38.2$ & $452.8 \pm 68.9$ \\
\hline \multirow[t]{3}{*}{$5 \mathrm{HT}$} & Cortex & $677.6 \pm 12.7$ & $415.5 \pm 11.1^{\mathrm{a}^{* *}}$ & & $371.7 \pm 19.1^{\mathrm{b}^{* *}}$ & $558.9 \pm 22.9^{\mathrm{b}^{*}}$ \\
\hline & Striatum & $364.1 \pm 0.6$ & $409.7 \pm 56.5$ & $252.2 \pm 37.4^{\mathrm{b}^{*}}$ & $283.3 \pm 56.7$ & $425.3 \pm 61.3$ \\
\hline & Hypothalamus & $704.9 \pm 67.7$ & $710.8 \pm 34.4$ & $551.5 \pm 7.7^{b^{*}}$ & $583.6 \pm 70.8$ & $729.1 \pm 47.2$ \\
\hline
\end{tabular}

Data are presented as means \pm SEM. $* \mathrm{p}<.05 ; * * \mathrm{p}<.01$

$\mathrm{a}=$ statistical significance by manipulation $(0.0 \mathrm{mg} / \mathrm{kg}$ group in relation to no gavage control group)

$\mathrm{b}=$ statistical significance by treatment (in relation to the $0.0 \mathrm{mg} / \mathrm{kg}$ group)

The two-way ANOVA showed alterations in cortical DOPAC/DA ratio by factor treatment $[\mathrm{F}(4,1,43)=17.52, \quad \mathrm{p}<.001] \quad$ with interaction $[\mathrm{F}(4,1,43)=4.06, \mathrm{p}<.01]$ between both factors. Striatal DOPAC/DA ratio were altered only by factor sex $[\mathrm{F}(4,1,43)=13.68, \quad \mathrm{p}<.001]$ and hypothalamic DOPAC/DA ratio were altered by factors treatment $[\mathrm{F}(4,1,43)=4.51, \mathrm{p}<.01]$ and sex $[F(4,1,43)=19.30, p<0.0001]$ with no interaction. The ordinary ANOVA showed reduced striatal DOPAC/DA ratio of male $0.0 \mathrm{mg} / \mathrm{kg}$ group when compared to the no gavage group. Cortical dopaminergic system activity was increased in the $3.0 \mathrm{mg} / \mathrm{kg}$ male and female groups and decreased in the $15.0 \mathrm{mg} / \mathrm{kg}$ female group $[\mathrm{F}(4,20)=15.898$, $\mathrm{p}<.05]$. The Tukey Kramer test showed increased striatal dopaminergic system activity in the 0.7 and the $3.0 \mathrm{mg} / \mathrm{kg}$ male and female groups, and also showed that females presents higher dopaminergic activity than males.
The two-way ANOVA showed striatal and hypothalamical VMA level alterations in factors treatment and sex [striatal: treatment $\mathrm{F}(4,1,43)=12.59, \quad \mathrm{p}<.001$; $\quad$ sex $\mathrm{F}(4,1,43)=29.69$, $\mathrm{p}<.001$; interaction $\mathrm{F}(4,1,43)=3.28, \quad \mathrm{p}<.05$; hypothalamic: treatment $\mathrm{F}(4,1,43)=3.21, \mathrm{p}<.05$; sex $F(4,1,43)=59.80, p<.001]$ with no interaction. The ordinary ANOVA showed increased striatal VMA levels in male and female $0.0 \mathrm{mg} / \mathrm{kg}$ animals [males: $\quad \mathrm{F}(4,20)=7.010, \quad \mathrm{p}<.01$; females: $\mathrm{F}(4,20)=27.617, \mathrm{p}<.01]$ when compared to the no gavage control group, decreased striatal $[\mathrm{F}(4,20)=7.010, \mathrm{p}<.01]$ VMA levels in the 0.7 and $3.0 \mathrm{mg} / \mathrm{kg}$ male groups, decreased VMA levels in the striatum of the $0.7,3.0$ and $15.0 \mathrm{mg} / \mathrm{kg}$ female groups $[\mathrm{F}(4,20)=27.617, \mathrm{p}<.01]$.

The two-way ANOVA revealed cortical NE level alterations in factors treatment $[\mathrm{F}(4,40)=3.56$, $\mathrm{p}<.05]$ and sex $[\mathrm{F}(1,40)=62.04, \mathrm{p}<.001]$. Also, revealed striatal [treatment $\mathrm{F}(4,40)=5.49, \mathrm{p}<.01$, interaction $\mathrm{F}(4,40)=3.24, \mathrm{p}<.05]$ and hypothalamic 
[treatment $\quad \mathrm{F}(4,40)=4.50, \quad \mathrm{p}<.01, \quad$ sex $\mathrm{F}(1,40)=40.92, \quad \mathrm{p}<.001] \quad \mathrm{VMA} / \mathrm{NE}$ ration alterations. The ordinary ANOVA showed increased striatal noradrenergic system activity $[F(4,20)=6.962, \mathrm{p}<.01]$ in the $0.0 \mathrm{mg} / \mathrm{kg}$ female group and decreased striatal $[\mathrm{F}(4,20)=6.962$, $\mathrm{p}<.01]$ noradrenergic activity in the $0.7,3.0$ and $15.0 \mathrm{mg} / \mathrm{kg}$ female groups.
The Tukey Kramer test showed decreased activity of the hypothalamic noradrenergic system in the $0.0 \mathrm{mg} / \mathrm{kg}$ female group when compared to the female no gavage control group, and increased hypothalamic noradrenergic activity in the 0.7 $\mathrm{mg} / \mathrm{kg}$ female group.

Table 2 - Effects of I. carnea AQE on central neurotransmitters (ng/g) of female adult rats exposed to different doses during gestation period (day 5 to 21 ).

\begin{tabular}{|c|c|c|c|c|c|c|}
\hline & Region & no gavage & & $\mathrm{AQE}$ & $(\mathrm{mg} / \mathrm{kg})$ & \\
\hline & & $(\mathbf{n}=5)$ & $0.0(n=5)$ & $0.7(n=5)$ & $3.0(n=5)$ & $15.0(n=5)$ \\
\hline DOPAC & Cortex & $13.7 \pm 1.5$ & $20.1 \pm 1.2$ & $19.2 \pm 3.3$ & $19.6 \pm 2.1$ & $8.9 \pm 0.7^{b^{* *}}$ \\
\hline & Striatum & $1560.7 \pm 277.7$ & $468.8 \pm 54.5^{\mathrm{a}^{*}}$ & $1556.4 \pm 192.0^{\mathrm{b}^{* * *}}$ & $1937.6 \pm 204.8^{b^{* *}}$ & $858.6 \pm 55.6$ \\
\hline & Hypothalamus & $53.7 \pm 3.3$ & $56.6 \pm 7.6$ & $74.2 \pm 17.7$ & $58.1 \pm 4.9$ & $47.4 \pm 4.3$ \\
\hline DA & Cortex & $21.3 \pm 1.8$ & $21.3 \pm 0.9$ & $12.2 \pm 1.8^{\mathrm{b}^{* *}}$ & $11.8 \pm 1.9^{\mathrm{b}^{* *}}$ & $22.1 \pm 2.3$ \\
\hline & Striatum & $2597.6 \pm 1013.1$ & $3440.6 \pm 1062.2$ & $2185.9 \pm 619.7$ & $2103.9 \pm 726.3$ & $3289.1 \pm 1249.5$ \\
\hline & Hypothalamus & $185.6 \pm 10.0$ & $173.4 \pm 26.1$ & $149.4 \pm 11.8$ & $131.6 \pm 17.4$ & $186.3 \pm 19.0$ \\
\hline VMA & Cortex & $80.2 \pm 37.7$ & $18.4 \pm 10.9$ & $41.4 \pm 25.9$ & $50.6 \pm 33.3$ & $17.1 \pm 11.2$ \\
\hline & Striatum & $67.1 \pm 3.7$ & $223.6 \pm 19.4^{\mathrm{a}^{* * *}}$ & $74.2 \pm 6.4^{\mathrm{b}^{* *}}$ & $74.2 \pm 4.1^{\mathrm{b}^{* *}}$ & $100.6 \pm 18.5^{\mathrm{b}^{* *}}$ \\
\hline & Hypothalamus & $64.0 \pm 14.9$ & $24.7 \pm 1.3$ & $50.6 \pm 16.6$ & $31.7 \pm 9.2$ & $24.8 \pm 6.7$ \\
\hline $\mathrm{NE}$ & Cortex & $53.2 \pm 3.8$ & $46.2 \pm 1.3$ & $48.9 \pm 6.7$ & $56.5 \pm 4.5$ & $41.2 \pm 2.5$ \\
\hline & Striatum & $48.0 \pm 3.6$ & $41.7 \pm 9.7$ & $44.5 \pm 3.2$ & $44.4 \pm 5.8$ & $43.5 \pm 5.4$ \\
\hline & Hypothalamus & $175.7 \pm 4.2$ & $183.3 \pm 6.6$ & $172.7 \pm 5.6$ & $174.6 \pm 13.5$ & $186.1 \pm 6.1$ \\
\hline 5HIIA & Cortex & $160.3 \pm 8.6$ & $198.6 \pm 12.1$ & $173.5 \pm 19.2$ & $161.3 \pm 25.9$ & $121.9 \pm 5.8^{\mathrm{b}^{*}}$ \\
\hline & Striatum & $259.2 \pm 30.6$ & $350.6 \pm 17.0$ & $315.3 \pm 18.7$ & $252.4 \pm 48.9$ & $298.9 \pm 26.7$ \\
\hline & Hypothalamus & $254.2 \pm 16.1$ & $280.2 \pm 19.3$ & $321.5 \pm 26.7$ & $213.5 \pm 47.5$ & $222.1 \pm 15.2$ \\
\hline $5 \mathrm{HT}$ & Cortex & $485.8 \pm 61.2$ & $283.8 \pm 24.8^{\mathrm{a}^{* *}}$ & $325.1 \pm 20.7$ & $202.9 \pm 45.8$ & $336.8 \pm 35.7$ \\
\hline & Striatum & $246.4 \pm 15.8$ & $157.0 \pm 31.5$ & $116.4 \pm 34.8^{\mathrm{b}^{*}}$ & $130.8 \pm 39.6$ & $189.6 \pm 38.5$ \\
\hline & Hypothalamus & $415.1 \pm 29.9$ & $487.6 \pm 50.3$ & $277.0 \pm 21.0^{\mathrm{b}^{*}}$ & $341.6 \pm 71.9$ & $353.7 \pm 58.1$ \\
\hline
\end{tabular}

The two-way ANOVA revealed 5HIAA cortex level alterations in factors treatment $[\mathrm{F}(4,40)=3.14, \mathrm{p}<.05]$ and sex $[\mathrm{F}(1,40)=52.88$, $\mathrm{p}<.001]$, with interaction $[\mathrm{F}(4,40)=3.36, \mathrm{p}<.05]$. Striatal 5HIAA level alterations were observed in factor sex $[\mathrm{F}(1,40)=51.59, \quad \mathrm{p}<.001]$ and hypothalamic 5HIAA level alterations were observed in factor treatment $[\mathrm{F}(4,40)=4.52$, $\mathrm{p}<.01]$. 5-HT level alterations were observed in the cortex [treatment $\mathrm{F}(4,40)=16.19, \mathrm{p}<.001$; sex: $\mathrm{F}(1,40)=54.67, \quad \mathrm{p}<.001], \quad$ striatum [treatment $\mathrm{F}(4,40)=3.88, \mathrm{p}<.01 ; \operatorname{sex} \mathrm{F}(1,40)=46.55, \mathrm{p}<.001]$ and hypothalamus [treatment $\mathrm{F}(4,40)=3.95, \mathrm{p}<.01$; sex $\quad F(1,40)=68.63, \quad \mathrm{p}<.001] . \quad$ The ordinary
ANOVA showed increased cortical $[F(4,20)=3.327, p<.05]$ 5HIAA levels in the 3.0 $\mathrm{mg} / \mathrm{kg}$ male group and decreased cortical $[\mathrm{F}(4,20)=2.971, \mathrm{p}<.05]$ 5HIAA levels in the 15.0 $\mathrm{mg} / \mathrm{kg}$ female group when compared to the 0.0 $\mathrm{mg} / \mathrm{kg}$ group.

The Tukey Kramer test showed increased hypothalamic 5HIAA levels in the male $0.0 \mathrm{mg} / \mathrm{kg}$ group when compared to the no gavage control group, decreased cortical 5HT levels in the $3.0 \mathrm{mg} / \mathrm{kg}$ male group, increased cortical 5HT levels in the $15.0 \mathrm{mg} / \mathrm{kg}$ male group and decreased striatal and hypothalamic 5HT levels in the 0.7 $\mathrm{mg} / \mathrm{kg}$ female group when compared to the 
$0.0 \mathrm{mg} / \mathrm{kg}$ group. Also showed higher 5-HT and 5HIAA levels in males than in females (in experimental and control groups).

The two-way ANOVA showed cortical 5HIAA/5HT ratio alterations in factors treatment $[F(4,40)=26.34, p<.001]$ and sex $[F(1,40)=9.33$, $\mathrm{p}<.01]$, with interaction $[\mathrm{F}(4,40)=11.10, \mathrm{p}<.001]$, also revealed hypothalamical ratio alterations in factor treatment $[\mathrm{F}(4,40)=5.89, \mathrm{p}<.001]$. The ordinary ANOVA showed increased cortical serotonergic system activity in male $[F(4,20)=9.195, \quad p<.05]$ and female $[F(4,20)=$ $10.105, \mathrm{p}<.05] 0.0 \mathrm{mg} / \mathrm{kg}$ group when compared to the no gavage control group. Also showed decreased cortical $[\mathrm{F}(4,20)=10.105, \quad \mathrm{p}<.05]$ serotonergic activity in the $15.0 \mathrm{mg} / \mathrm{kg}$ female group.

The Tukey Kramer test showed increased cortical and striatal serotonergic system activities in the $3.0 \mathrm{mg} / \mathrm{kg}$ male group and increased hypothalamic serotonergic system activity in the $0.7 \mathrm{mg} / \mathrm{kg}$ male group. Also, increased hypothalamic serotonergic activity in the $0.7 \mathrm{mg} / \mathrm{kg}$ female group and higher striatal serotonergic activity in females than males, were observed.
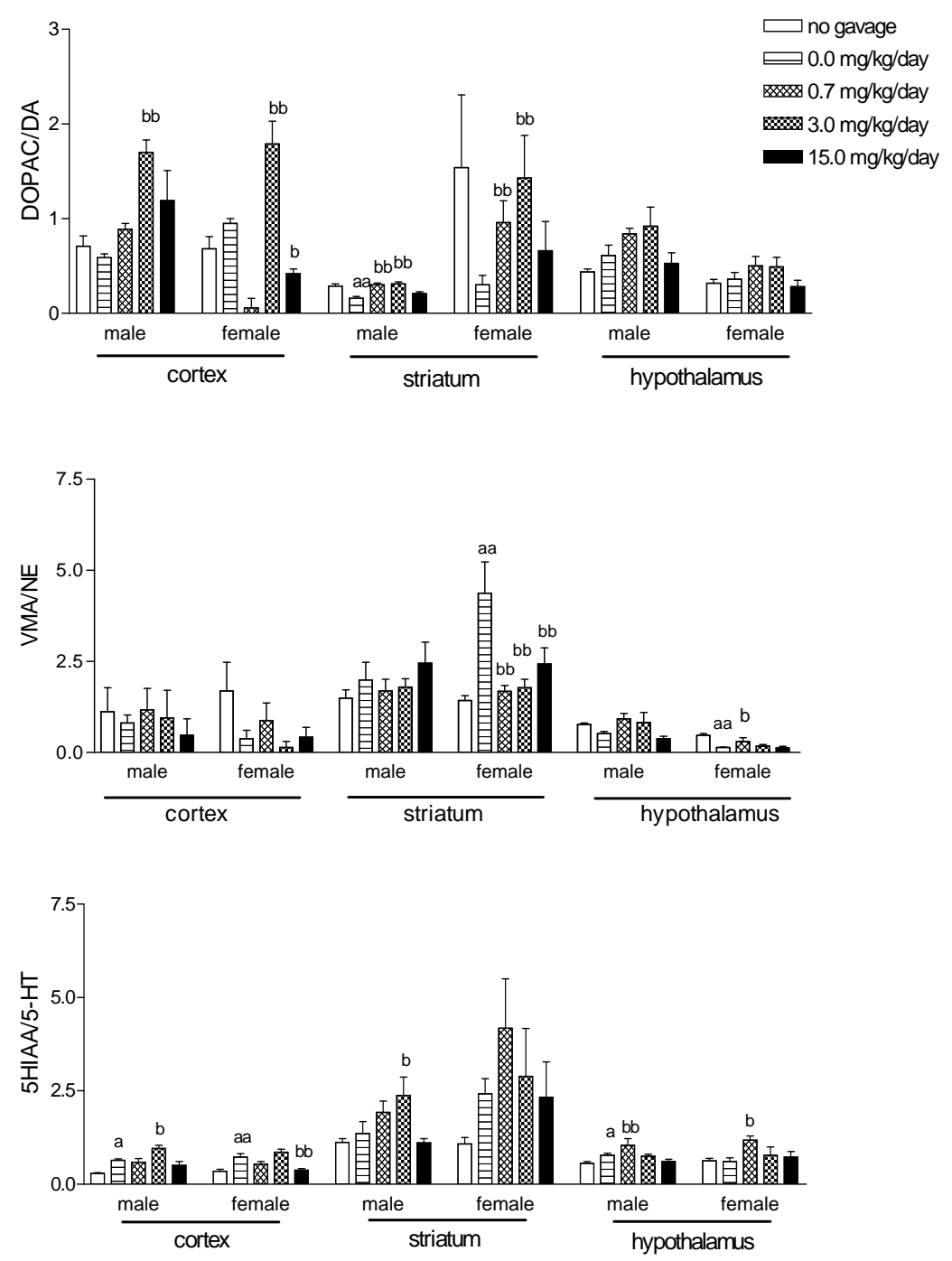

Figure 1 - Effects of I. carnea AQE on metabolite/neurotransmitter ratio of male and female adult rats. (n=5/group) * $p<.05 ; * * p<.01 . \quad \mathrm{a}=$ statistical significances by manipulation $(0 \mathrm{mg} / \mathrm{kg} \mathrm{AQE}$ group in relation to no gavage control group). $\mathrm{b}=$ statistical significances by treatment (in relation to $0 \mathrm{mg} / \mathrm{kg} \mathrm{AQE}$ group). 


\section{DISCUSSION}

It is well known that stress during the critical period of organogenesis promotes changes in maternal behavior and in postnatal offspring development. Hence, a non-manipulated group (no gavage control group) was employed in this study to evaluate the possible noxious effects of stress induced by the gavage procedure.

Manipulation caused alterations in neurotransmitter levels and in their system activities. It is well known that maternal stress affects physiological and behavioral functions in the offspring, and that in the immature brain many neurotransmitters acts as developmental signals or regulators, resulting in permanent changes in the densities of several neurotransmitter receptors once the brain has matured (Ogawa et al., 1994). In addition, other studies revealed that prenatal stress reduces dopamine neurotransmission in the ventral striatum (Wang et al., 1995) and that changes in catecholamine and, especially in brain noradrenaline levels, have been associated with behavioral deficits caused by stress exposure (Mendels et al., 1972; Simpson and Weiss, 1988). This was the basis in this study to speculate about the stress effects of gavage on the neurotransmitter systems of the $0 \mathrm{mg} / \mathrm{kg}$ and the other experimental groups, as several alterations were observed without behavioral changes, perhaps because of alternative pathways developed by the CNS of these animals, promoting a normal life.

Previous studies have demonstrated that during ontogeny, when the central nervous system is incompletely developed, paradoxical and enduring effects of exposure to agonists and antagonists occur. Rat pups with serotonin depletion by methyldiethylmethamphetamine exposure, for example, show no changes in weight gain or locomotor activity (Winslow and Insel, 1990). Also, adverse effects produced by I. carnea aqueous extract by gavage orally intake during gestation, did not promote significant neurobehavioral changes in the offspring when they reached adult age (Schwarz et al., 2003). In this paper the authors studied monoamine levels without considering the sex. However, in the present study many changes were observed in the male and female central neurotransmitter systems, suggesting a higher sensitivity of cerebral monoamine determination level procedure than behavioral measures and a sexual dimorphism. In these cases, the target system was still developing and the property of central nervous system plasticity might persist through this period. In addition, metabolic central nervous system enzymes and the blood-brain barrier were maturing postnatally, ensuring very different pharmacokinetic profiles during development (Saunders and Mollgard, 1984).

Several alterations on the levels of neurotransmitters and their metabolites were observed in the animals employed. However, the data obtained did not attribute the changes to any specific component of the treatment, once both sex differences in control levels, and most importantly, major differences in the $0.0 \mathrm{mg} / \mathrm{kg}$ vs control gavage groups were observed.

In summary, the present study showed that the several changes in the central monoamine activity systems did not alter the behavior analyzed during adulthood in previous studies (Schwarz et al., 2003). The control data suggested that gavage and handling of dams was stressful enough to produce a significant decline in DOPAC (a measure of DA metabolism) and an increase in VMA, indicating enhanced NE activity. Perhaps there was little transfer of the toxic agents of the plant to the fetus and the fetotoxic effects were maternally mediated. An alternative hypothesis could be that, in rats, the main effects of swainsonine and calystegines occurred outside the central nervous system. In any case, this study could not completely ruled out the effects of I. carnea on the central nervous system as a whole.

\section{ACKNOWLEDGMENTS}

This work was supported by grants from Fundação de Amparo à Pesquisa do Estado de São Paulo (FAPESP) and is part of the Master's thesis presented by Aline Schwarz to the Faculdade de Ciências Farmacêuticas da Universidade de São Paulo. Special thanks to Dra Mitsue Haraguchi for the leaves extraction technical assistance. 


\section{RESUMO}

Estudo anterior realizado em filhotes de ratas tratadas diariamente por gavage com $0,0,0,7,3,0 \mathrm{e}$ $15,0 \mathrm{mg} / \mathrm{kg}$ de uma solução aquosa obtida de folhas frescas da Ipomoea carnea, do dia 5 ao dia 21 da gestação, mostrou poucas alterações comportamentais na prole em vida adulta. O presente estudo teve como objetivo avaliar a atividade e níveis das monoaminas cerebrais nas proles masculina e feminina expostas ao mesmo tratamento acima descrito. As maiores alterações encontradas, entretanto, foram entre os grupos 0,0 $\mathrm{mg} / \mathrm{kg}$ e controle negativo (no gavage), impedindo a atribuição das alterações encontradas à solução aquosa. O dados resultantes do grupo controle sugerem que o estresse provocado pela gavage e pelo manuseio das fêmeas enquanto prenhes é suficiente para produzir um importante declínio nos níveis do ácido 3,4 dihidroxifenilacético (DOPAC) e um não menos importante aumento nos níveis do ácido vanilmandélico (VMA), promovendo maior atividade do sistema noradrenérgico (NE).

\section{REFERENCES}

Asano, N., Nash, R.J., Molyneux, R.J., Fleet, G.W.J., (2000). Sugar-mimic glycosidase inhibitors: natural occurrence, biological activity and prospects for therapeutic application. Tetrahedron Assym., 11, 1645-1680.

Asano, N., Yokoyama, K., Sakurai, M., Ikeda, K., Kizu, H., Kato, A., Arisawa, M., Hoke, D., Dräger, B., Watson, A.A., Nash, R.J., (2001). Dihydroxynortropane alkaloids from calystegineproducing plants. Phytochemistry, 57, 721-726.

Bowen, D., Adir, J., White, S.L., Bowen, C.D., Matsumoto, K., Olden, K., (1993). A preliminary pharmacokinetic evaluation of the antimetastatic immunomodulator swainsonine: clinical and toxic implications. Anticancer Res., 13, 841-844.

Damir, H.A., Adam, S.E.I., Tartour, G., (1987). Effects of Ipomoea carnea on goats and sheep. Vet. Human Toxicol., 29, 316-319.

De Balogh, K.I.M., Dimande, A.P., Van der Lugt, J.J, Molyneux, R.J., Naudé, T.W., Welman, W.G., (1999). A lysosomal storage disease induced by Ipomoea carnea in goats in Mozambique. J. Vet. Diagn. Invest., 11, 266-273.
Felício, L.F., Flório, J.C., Sider, L.H., CruzCasallas,P.E., Bridges, R.S., (1996). Reproductive experience increases striatal and hypothalamic dopamine levels in pregnant rats. Brain Res. Bul., 40, 253-256.

Idris, O.F., Tartour, G., Adam, S.E.I., Obeid, H.M., (1973). Toxicity to goats of Ipomoea carnea. Trop. Anim. Health Prod., 5, 119-123.

Keeler, R.F. (1988). Livestock models of human birth defects, reviewed in relation to poisonous plants. J. Animal Sci., 66, 2414-2427.

Mendels, J., Frazer, A., Fitzgerald, R. J., Ramsey, T. A., Stokes, J. W., (1972). Biogenic amines metabolites fluid of depressed and maniac patients, Science, 20, 1380-1381.

Ogawa, T., Mikuni, M., Kuroda, Y., Muneoka, K., Mori, K.J., Takahashi, K., (1994). Periodic maternal deprivation alters stress response in adult offspring: potentiates the negative feedback regulation of restraint stress-induced adrenocortical response and reduces the frequencies of open field-induced behaviors. Pharmacol. Biochem. Behav., 49, 961-967.

Panter, K.E., Ralphs, M.H., James, L.F., Stegelmeier, B.L., Molyneux, R.J., (1999). Effects of locoweed (Oxytropis sericea) on reproduction in cows with a history of locoweed consumption. Vet. Human. Toxicol., 41, 282-286.

Saunders, N.R., Mollgard, K., (1984). Development of the blood-brain barrier. J. Dev. Physiol., 6, 45-57.

Schumaher-Henrique, B., Górniak, S.l., Cagli, M.L.Z., Spinosa, H.S., (2003). The clinical, biochemical, haematological and pathological effects of long-term administration of Ipomoea carnea to growing goats. Vet. Res. Commun., 27, 311-319.

Schwarz, A., Górniak, S.L., Bernardi, M.M., Dagli, M.L.Z., Spinosa, H.S., (2003). Effects of Ipomoea carnea aqueous fraction intake by dams during pregnancy on the physical and neurobehavioral development of rat offspring. Neurotoxicol. Teratol., 25, 615-626.

Schwarz, A. Hosomi, R.Z., Schumaher-Henrique, B., Hueza, I.M., Garder, D., Haraguchi, M. Górniak, S.L., Bernardi, M.M., Spinosa, H.S., (2004). Identificação de princípios ativos presentes na Ipomoea carnea brasileira. Rev. Brasileira Ciênc. Farmacêuticas, 40 (2), 181-187.

Simpson, P.E., Weiss, J.M., (1988). Altered activity of the locus coeruleus in an animal model of depression. Neuropsychopharmacology, 1, 287-295.

Stegelmeier, B.L., James, L.F., Panter, K.E., Gardner, D.R., Ralphs, M.H., Pfister, J.A., (1998). Tissue swainsonine clearence in sheep chronically poisoned with locoweed (Oxytropis sericeae). J. Anim. Sci., 76, 1140-1144.

Stegelmeier, B.L., Molyneux, R.J., Elbdein, A.D., James, L.F., (1995). The lesions of locoweed (Astragalus molissimus) swainsonine and castanospermine in rats. Vet. Pathol., 32, 289-298. 
Tokarnia, C.H., Dobereiner, J., Canella, C.F.C., (1960). Estudo experimental sobre a toxidez do "canudo" (Ipomoea fistulosa Mart.) em ruminantes. Arq. Inst. Biol. Animal, 3, 59-71.

Wang, C.T., Huang, R.L., Tai, M.Y., Tsai, Y.F., Peng, M.T., (1995). Dopamine release in the nucleus accumbens during sexual behavior in prenatally stressed adult male rats. Neurosci. Lett., 200, 29-32.

Winslow, J. T., Insel, T. R., (1990). Serotoninergic modulation of rat pup ultrasonic vocal development: $\quad$ studies with 3,4methylenodioximethamphetamine. J. Pharmacol. Exp. Ther., 254, 212-220. 
PÁGINA

EM

BRANCO 